\title{
Edukasi Pemanfaatan Biji Kelor Sebagai Pasta Gigi Kepada Pendamping Lansia di Masa Pandemi Covid 19
}

\author{
Sugiyanto, Wibowo, Venny Kurnia Andika \\ STIKes Panti Waluya Malang \\ Email: sugiyantomatoya@gmail.com
}

\begin{abstract}
Abstrak
Kesehatan gigi dan mulut merupakan bagian dari kesehatan tubuh secara keseluruhan, dikarenakan dapat mempengaruhi kualitas kehidupan, termasuk fungsi bicara, pengunyahan dan rasa percaya diri.terutama lansia. Salah satu cara untuk mencegah terjadinya masalah kesehatan gigi dan mulut adalah dengan menyikat gigi menggunakan pasta gigi. Salah satu fungsi dari pasta gigi adalah memelihara kesehatan gigi. Tujuan dalam pengabdian masyarakat ini untuk mengenalkan potensi dalam membuat pasta gigi untuk meningkatkan kesehatan gigi dan mulut dimasa pandemi. Metode pelaksanaan dengan menggunakan media online yaitu zoom dalam kegiatan pengabdian masyarakat kepada grup pendamping lansia yang meliputi 3 kegiatan antara lain:Tahap persiapan: melakukan pendekatan, persiapan bahan dan alat yang digunakan untuk pembuatan pasta gigi; Tahap pelaksanaan: memberikan edukasi kesehatan dan pelatihan terkait manfaat, cara penggunaan, dan penyebaran video; Tahap evaluasi dilakukan terhadap apresiasi grup. Hasil dari dilakukannya pengabdian adalah dapat berjalan baik dan lancar sesuai dengan yang telah dijadwalkan, hal tersebut sesuai dengan jumlah prosentase dengan nilai ratarata $90 \%$ setuju yang didapat dari jawaban kuesioner google form yang diberikan pada pendamping lansia. Kesimpulan bahwa tujuan untuk meningkatkan pengetahuan terkait pemanfaatan biji kelor yang digunakan sebagai pasta gigi herbal khusus untuk lansia kepada para pendamping lansia dapat tercapai. Saran kegiatan pengabdian ini sebaiknya dilakukan secara berkesinambungan serta terjadwal.
\end{abstract}

Kata kunci : Kesehatan gigi, Pasta gigi herbal, Biji kelor, Lansia

\begin{abstract}
Dental and oral health is part of the overall health of the body, because it can affect the quality of life, including the function of speech, mastication and self-confidence, especially the elderly. One way to prevent dental and oral health problems is to brush your teeth using toothpaste. One of the functions of toothpaste is to maintain dental health. The purpose of this community service is to introduce the potential in making toothpaste to improve oral and dental health during the pandemic. The implementation method using online media is zoom in community service activities for elderly companion groups which includes 3 activities, including: Preparation stage: approaching, preparing materials and tools used for making toothpaste; Implementation stage: providing health education and training related to the benefits, how to use, and distribution of videos; The evaluation stage is carried out on group appreciation. The results of the service are that it can run well and smoothly according to what has been scheduled, this is in accordance with the number of percentages with an average value of $90 \%$ agree obtained from the answers to the google form questionnaire given to elderly companions. The conclusion that the goal of increasing knowledge related to the use of Moringa seeds used as a special herbal toothpaste for the elderly to elderly companions can be achieved. Suggestions for this service activity should be carried out continuously and on a scheduled basis.
\end{abstract}

Keywords : Dental health, Herbal toothpaste, Moringa seeds, Elderly

http://ejournal.urindo.ac.id/index.php/PAMAS

Article History :

Submitted 23 Maret 2021, Accepted 26 Oktober 2021, Published 31 Oktober 2021 


\section{PENDAHULUAN}

\section{Analisis situasi}

Menurut riset kesehatan dasar pada tahun 2013 menunjukkan adanya masalah kesehatan gigi dan mulut penduduk Indonesia yang mencapai 25,9\% dan meningkat menjadi 57,6 \% di tahun 2018. Dari data ini terlihat bahwa masyarakat Indonesia yang mempunyai masalah gigi semakin meningkat (Kemenkes, 2018). Tantangan yang dihadapi Indonesia berkaitan dengan status kesehatan gigi dan mulut yang buruk pada anak-anak dan berlanjut hingga usia remaja dan lansia. Dimana pada lansia terjadi kemunduran sel-sel karena proses penuaan. Akibatnya muncul gejala seperti kelemahan organ, kemunduran fisik, dan timbulnya berbagai macam penyakit. salah satu hal yang mengalami kemunduran adalah kesehatan gigi lansia.(Utari, 2018). Hal tersebut diatas sesuai dengan kondisi lansia di group pengabdian masyarat kami dimana banyak mempunyai masalah di kesehatan gigi. Kesehatan gigi yang buruk akan mempengaruhi kualitas hidup lansia. Banyak para lansia yang tidak lagi memperhatikan dan menjaga kesehatan giginya secara baik karena kesehatan fisiknya terganggu. Padahal, memelihara kesehatan gigi lansia merupakan hal penting. Kurangnya menjaga kebersihan dan kesehatan gigi dapat mengakibatkan invasi bekteri dan menimbulkan penyakit. Beberapa penelitian kedokteran gigi telah menemukan bahwa bakteri yang terdapat di dalam mulut merupakan salah satu penyebab stroke. Untuk mencegah dan meminimalisir gangguan kesehatan di kelompok lansia, maka pasta gigi yang dipilih oleh kelompok lansia sebaiknya tidak mengandung sodium lauryl sulfate atau detergen. Detergen tak hanya membuat mulut kering tetapi juga mengurangi saliva yang ada di dalam mulut inilah penyebab gigi berlubang, bau mulut, sariawan, dan masalah mulut lainnya. Maka diperlukan pasta gigi yang mengandung bahan yang aman dan nyaman serta memiliki efek samping yang kecil, hal ini biasanya didapatkan dari bahan-bahan yang terbuat dari herbal, yang salah satunya adalah pasta gigi herbal yang bahan kandungannya adalah biji kelor dimana biji kelor ini banyak terdapat antioksidan yang berfungsi untuk meningkatkan kesehatan gigi, mengurangi rasa nyeri, mencegah infeksi. Target dalam mencapai upaya pencegahan dan perbaikan status kesehatan sangat dibutuhkan kolaberasi yang efektif dan komunikatif antara pendamping lansia dengan tenaga kesehatan profesional. Jumlah tenaga kesehatan profesional yang sangat terbatas, sehingga mengharuskan pendamping lansia dapat menjadi partner bagi tenaga kesehatan di sektor promotif kesehatan. (Nurdianti1 et al., 2016).

Prevalensi yang banyak untuk penyakit gigi dan mulut yang ada pada masyarakat salah satunya menjadi alasan pengabdian masyarakat dilaksanakan kepada para pendamping lansia di masyarakat, sehingga dapat meningkatkan kesehatan di masyarakat melalui strategi pemberian 


\section{Jurnal Pelayanan dan Pengabdian Masyarakat (PAMAS)}

edukasi pada pendamping lansia yang ada dimasyarakat didaerah Kabupaten Malang. Hasil riset kesehatan dasar pada tahun 2013 menunjukkan adanya masalah kesehatan gigi dan mulut penduduk Indonesia yang mencapai $25,9 \%$ dan meningkat menjadi $57,6 \%$ di tahun 2018. Dari data ini terlihat bahwa masyarakat Indonesia yang mempunyai masalah gigi semakin meningkat (Kemenkes, 2018). Tantangan yang dihadapi Indonesia berkaitan dengan status kesehatan gigi dan mulut yang buruk pada anak-anak dan berlanjut hingga usia remaja dan lansia. Dimana pada lansia terjadi kemunduran sel-sel karena proses penuaan, salah satu hal yang mengalami kemunduran adalah kesehatan gigi dan mulut lansia.(Astika, Saputro, \& Harismah, 2020). Permasalahan-permasalahan mitra yang telah diuraikan tersebut menjelaskan bahwa permasalahan prioritas untuk diberikan intervensi yaitu tingginya prevalensi jenis penyakit gigi dan mulut pada lansia yang dapat menyebabkan terjadinya komplikasi yang sangat merugikan bagi lansia. Berikut ini berbagai masalah kesehatan gigi yang sering kali dialami lansia: Nyeri gigi atau sakit gigi, Ompong atau tidak bergigi, Penyakit gusi, Mulut kering, Sariawan, serta Kanker mulut. Untuk mencegah dan meminimalisir gangguan kesehatan di kelompok lansia, maka para orang tua sebaiknya banyak mengkonsumsi air putih dan buah-buahan. Selain itu, mereka seharusnya tetap rajin menggosok gigi setelah makan dan sebelum tidur.(Ardiani \& Meilani, 2020).

\section{RUMUSAN MASALAH}

Berdasarkan latar belakang di atas dapat dirumuskan masalah penelitian sebagai berikut:

1. Masih kurangnya pengetahuan masyarakat pendamping lansia tentang kesehatan gigi dan mulut pada lansia

2. Masih minimnya produk pasta gigi herbal khusus digunakan pada lansia meningkatkan kesehatan gigi dan mulut

3. Pemanfaatan bahan alam (biji kelor) sebagai pasta gigi herbal yang masih jarang dimanfaatkan

\section{METODE}

Metode yang digunakan dalam kegiatan pengabidian masyarakat pendamping lansia ini menggunakan media online yaitu zoom dengan kegiatan seperti dibawah ini.

\section{Tahap Persiapan}

Pendekatan yang perlu dilakukan untuk mencapai target dan luaran yang optimal dengan menggunakan media sosial antara lain: Pembuatan video tentang pengenalan potensi dan pembuatan pembuatan pasta gigi herbal, serta mengupload video ke media social (youtube). 


\section{Tahap pelaksanaan}

Pelaksanaan Pemberdayaan pendamping lansia dalam pengenalan potensi dan pembuatan pasta gigi herbal untuk meningkatkan kesehatan gigi dan mulut dimasa pandemi Covid 19.

Dilakukan dengan cara antara lain: Memberikan pengetahuan tentang bahan alam yang bisa digunakan untuk meningkatkan kesehatan gigi dan mulut bagi lansia, pembuatan pasta gigi herbal untuk meningkatkan kesehatan gigi dan mulut bagi lansia

\section{Bentuk Pengabdian Kepada Masyarakat}

Penyuluhan mengenai pemberdayaan pendamping lansia dalam pengenalan potensi dan pembuatan pasta gigi herbal untuk meningkatkan kesehatan gigi dan mulut bagi lansia dimasa pandemi Covid 19; Penyuluhan prosedur pembuatan pasta gigi herbal untuk meningkatkan kesehatan gigi dan mulut bagi lansia dimasa pandemi Covid 19.

\section{Tahap evaluasi}

Evaluasi dilakukan terhadap apresiasi masyarakat terutama pendamping lansia yang mengikuti konten media social (youtube) dengan menggunakan lembar kuesioner pada aplikasi google form.

\section{Hasil Kegiatan Pengabdian Masyarakat}

Tabel Kegiatan dan Hasil Kegiatan PkM di Kabupaten Malang

\begin{tabular}{|c|c|c|c|}
\hline Waktu & Kegiatan & Tujuan & Hasil \\
\hline 1 Agustus 2021 & Membuat laporan PkM & $\begin{array}{ll}\text { Melaksanakan } & \text { Tri } \\
\text { Dharma } & \end{array}$ & $\begin{array}{l}\text { Terlaksanannya } \\
\text { kegiatan Tri Dharma }\end{array}$ \\
\hline 4 Agustus 2021 & $\begin{array}{l}\text { Upload laporan kegiatan } \\
\text { PkM ke LPPM }\end{array}$ & $\begin{array}{l}\text { Melaksanakan } \\
\text { Tri Dharma }\end{array}$ & $\begin{array}{l}\text { Terlaksanannya } \\
\text { kegiatan Tri Dharma }\end{array}$ \\
\hline 15 Desember 2021 & $\begin{array}{l}\text { Persiapan Bahan Baku biji } \\
\text { kelor } \\
\text { - Sortasi biji kelor } \\
\text { - Pengeluaran biji kelor } \\
\text { - Pengeringan biji kelor }\end{array}$ & $\begin{array}{l}\text { Mendapatkan simplisia } \\
\text { biji kelor yang kering }\end{array}$ & 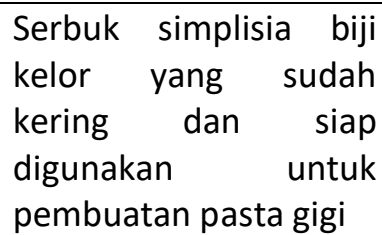 \\
\hline 24 Desember 2021 & $\begin{array}{l}\text { Pembelian bahan } \\
\text { pembantu yang digunakan } \\
\text { untuk pasta gigi } \\
\text { - CaCO3 } \\
\text { - NaCMC } \\
\text { - Lauril SO4 } \\
\text { - Gliserin } \\
\text { - Nipagin } \\
\text { - Aquades }\end{array}$ & $\begin{array}{ll}\text { Sebagai } & \text { bahan } \\
\text { pembantu } & \text { (/basis } \\
\text { pasta gigi) } & \text { dalam } \\
\text { pembuatan pasta gigi }\end{array}$ & $\begin{array}{l}\text { Didapatkan bahan } \\
\text { tambahan dari } \\
\text { Distributor bahan- } \\
\text { bahan farmasi (PBF } \\
\text { bahan baku) }\end{array}$ \\
\hline 11 Januari 2021 & $\begin{array}{l}\text { Minta Surat Pengantar } \\
\text { Permohonan PkM ke SMA } \\
\text { Negeri Sumber Pujung ke }\end{array}$ & $\begin{array}{lr}\text { Sebagai } & \text { surat } \\
\text { permohonan } & \text { ijin } \\
\text { pelaksanan } & \text { PkM }\end{array}$ & $\begin{array}{l}\text { Dibuatkan } \quad \text { surat } \\
\text { pengantar } \\
\text { permohonan }\end{array}$ \\
\hline
\end{tabular}




\begin{tabular}{|c|c|c|c|}
\hline & LPPM & $\begin{array}{l}\text { sekolah SMA Negeri } \\
\text { Sumber Pujung Malang }\end{array}$ & $\begin{array}{l}\text { SMA Negeri Sumber } \\
\text { Pujung Malang }\end{array}$ \\
\hline 14 Januari 2021 & $\begin{array}{l}\text { Mengantar Surat } \\
\text { Pengantar Permohonan } \\
\text { PkM ke SMA Negeri } \\
\text { Sumber Pujung Malang ke } \\
\text { WaKa Kesiswaan SMA } \\
\text { Negeri Sumber Pujung } \\
\text { Malang }\end{array}$ & $\begin{array}{l}\text { Meminta persetujuan } \\
\text { ke WaKa Kesiswaan } \\
\text { SMA Negeri Sumber } \\
\text { Pujung Malang untuk } \\
\text { melakukan kegiatan } \\
\text { PkM di sekolah } \\
\text { tersebut }\end{array}$ & $\begin{array}{l}\text { Disetujuinya } \\
\text { melakukan kegiatan } \\
\text { PkM oleh WaKa } \\
\text { Kesiswaan SMA Negeri } \\
\text { Sumber Pujung Malang } \\
\text { untuk melakukan } \\
\text { kegiatan PkM di } \\
\text { sekolah tersebut }\end{array}$ \\
\hline 15 Januari 2021 & $\begin{array}{l}\text { Melakukan kegiatan } \\
\text { 1.Pembuatan sediaan } \\
\text { pasta } \\
\text { gigi herbal } \\
\text { 2.Pengambilan video pada } \\
\text { saat pembuatan sediaan } \\
\text { sediaan pasta gigi herbal }\end{array}$ & $\begin{array}{l}\text { Dari kegiatan tersebut } \\
\text { 1.Didapatkan sediaan } \\
\text { pasta gigi herbal } \\
\text { 2.didapatkan video } \\
\text { pembuatan sediaan } \\
\text { pasta gigi herbal }\end{array}$ & $\begin{array}{l}\text { Hasil yang didapatkan } \\
\text { 1. Sediaan pasta gigi } \\
\text { herbal } \\
\text { 2. Video pembuatan } \\
\text { sediaan pasta gigi } \\
\text { herbal }\end{array}$ \\
\hline 20 Januari 2021 & Edit video & $\begin{array}{l}\text { Didapatkan hasil video } \\
\text { yang baik }\end{array}$ & $\begin{array}{ll}\text { Video pembuatan } \\
\text { sediaan }\end{array}$ \\
\hline 21 Januari 2021 & $\begin{array}{l}\text { Pengumpulan video ke } \\
\text { LPPM }\end{array}$ & $\begin{array}{l}\text { Untuk mendapatkan } \\
\text { link edukasi }\end{array}$ & Link edukasi \\
\hline 8 Februari 2021 & $\begin{array}{l}\text { Share link edukasi ke } \\
\text { pendamping lansia }\end{array}$ & $\begin{array}{lr}\text { Untuk memberikan } \\
\text { edukasi } \\
\text { pendamping lansia } \\
\text { tentang pembuatan } \\
\text { sediaan pasta gigi } \\
\text { herbal yang disertai } \\
\text { dengan edukasi }\end{array}$ & $\begin{array}{lr}\text { Tanya } & \text { jawab melalui } \\
\text { grup } & \text { pendamping } \\
\text { lansia } & \end{array}$ \\
\hline 9 Februari 2021 & $\begin{array}{l}\text { Evaluasi melalui pengisian } \\
\text { lembar google form }\end{array}$ & $\begin{array}{l}\text { 1.Mengukur tingkat } \\
\text { ksesuaian sediaan yang } \\
\text { dibuat dengan } \\
\text { kesesuaian partisipan } \\
\text { 2.Mengukur } \\
\text { keberhasilan proses } \\
\text { pemberian edukasi }\end{array}$ & $\begin{array}{l}\text { 1. Jumlah prosentase } \\
\text { yang bagus } \\
\text { 2. Pendamping lansia } \\
\text { mendapat edukasi } \\
\text { yang lengkap dan tepat }\end{array}$ \\
\hline
\end{tabular}

\section{PEMBAHASAN}

Hasil kegiatan pengabdian kepada masyarakat dengan topik Pemberian Edukasi Terhadap Pemanfaatan Biji Kelor yang digunakan Sebagai Pasta Gigi Herbal kepada Pendamping Lansia di Masa Pandemi Covid 19, digunakannya biji kelor dalam pembuatan Pasta Gigi Herbal ini disebabkan kandungan biji kelor banyak terdapat kandungan kalsium dari buah kelor sangat tinggi sehingga sangat dimungkinkan untuk bahan dasar pasta gigi karena kalsium berperan sebagai bahan abrasif yang terdapat dalam pasta gigi yang berfungsi untuk membersihkan dan memoles permukaan gigi tanpa merusak email, mempertahankan ketebalan pelikel, serta mencegah akumulasi stain. Bentuk dan jumlah bahan abrasif dalam pasta gigi membantu untuk menambah kekentalan pasta gigi 


\section{Jurnal Pelayanan dan Pengabdian Masyarakat (PAMAS)}

(Ahmad.M, Supardi \& Siti.N, 2016). Kegiatan pengabdian masyarakat ini dapat berjalan dengan baik dan lancar sesuai dengan yang telah dijadwalkan oleh tim pengabdian Masyarakat STIKes Panti Waluya Malang. Kegiatan pengabdian masyarakat ini dimulai dari Persiapan Bahan Baku biji kelor yang dilakukan dengan sortasi biji kelor, pengeluaran biji kelor dan pengeringan biji kelor, pembelian bahan pembantu yang digunakan untuk pasta gigi antara lain $\mathrm{CaCO}$, $\mathrm{Na} \mathrm{CMC}$, Lauril SO4, Gliserin, Nipagin dan Aquades, melakukan kegiatan pengantaran Surat Pengantar Permohonan PkM ke SMA Negeri Sumber Pujung yang merupakan mita PkM dan melakukan kegiatan pembuatan sediaan pasta gigi herbal serta pengambilan video pada saat pembuatan sediaan pasta gigi herbal, melakukan edit video, share link edukasi ke pendamping lansia dalam pelaksanaan kegiatan pengabdian masyarakat dan pelaksanaan evaluasi melalui pengisian lembar google form. Keberhasilan pengabdian masyarakat ini berkat kerjasama yang baik antara tim pengabdian masyarakat STIKes Panti Waluya dalam pembuatan sediaan pasta gigi herbal serta para partisipasi pendamping lansia. Peran aktif peserta pendamping lansia dalam kegiatan PkM " Pemberian Edukasi Terhadap Pemanfaatan Biji Kelor yang digunakan sebagai Pasta Gigi Herbal kepada Pendamping Lansia di Masa Pandemi Covid 19" ini dapat disimpulkan berjalan baik tanpa hambatan yang berarti. Dari hasil kuisioner yang telah diberikan melalui google form pada partisipan didapatkan poin sebagai berikut :

Jumlah prosentase yang didapat pada pertanyaan no.5 "Apakah pelatihan yang disampaikan sesuai dengan harapan anda" partisipan yang memberikan jawaban sangat setuju ada $20 \%$ dan yang setuju adalah 80\%; pertanyaan no.6 "Apakah pelatihan ini bermanfaat bagi anda" partisipan yang memberikan jawaban sangat setuju dan setuju masing-masing adalah 50\%; pertanyaan no.7 "apakah pelatihan sabun cair ini dapat memotivasi/dan memberikan ide baru bagi anda" partisipan yang memberikan jawaban sangat setuju dan setuju adalah sama yaitu 50\%; pertanyaan no.8 "apakah cara pembuatan sabun cair ini mudah anda pahami" partisipan yang memberikan jawaban sangat setuju $20 \%$, setuju $70 \%$, dan tidak setuju 10\%; pertanyaan no.9 "apakah keseempatan diskusi tanya jawab yang disediakan cukup" partisipan yang memberikan jawaban sangat setuju $10 \%$ dan setuju 90\%; pertanyaan no.10 "apakah interaksi narasumber dengan peserta sudah berjalan dengan baik" partisipan yang memberikan jawaban sangat setuju $20 \%$ dan setuju $80 \%$; pertanyaan no.11 "apakah isi pelatihan ini menyenangkan" partisipan yang memberikan jawaban sangat setuju $40 \%$, setuju $50 \%$, dan tidak setuju 10\%; pertanyaan no.12 "apakah jawaban dari narasumber dalam menjelaskan materi dapat memuaskan anda" partisipan yang memberikan jawaban sangat setuju $30 \%$, setuju $60 \%$, dan tidak setuju 10\%; pertanyaan no.13 "apakah durasi waktu pelatihan ini sudah sesuai dengan waktu yang telah disediakan" partisipan yang memberikan jawaban sangat setuju $30 \%$ dan 
setuju 70\%; pertanyaan no.14 "apakah narasumber menguasai materi yang disampaikan" partisipan yang memberikan jawaban sangat setuju $40 \%$ dan setuju $60 \%$.

\section{KESIMPULAN}

Pelaksanaan kegiatan pengabdian masyarakat yang dilakukan oleh tim STIKes Panti Waluya Malang terhadap partisipasi pendamping lansia dapat berjalan dengan baik, lancar, dan sukses, hal ini tercermin pada saat pemberian materi edukasi, cara pembuatan sediaan dengan menggunakan video melalui media online dengan baik dan lancar serta peran partisipan pendamping lansia yang aktif mengikuti edukasi tersebut.

\section{UCAPAN TERIMA KASIH}

Yayasan Pendidikan Misericordia, Bapak Wibowo,S.Kep.,Ns.,M.Biomed, Selaku Ketua STIKes Panti Waluya Malang, Grup pendamping lansia, Rekan-rekan di STIKes Panti Waluya Malang

\section{DAFTAR PUSTAKA}

1. Ardiani, Ir., \& Meilani, D. (2020). Pembuatan Sediaan Pasta Gigi dari Bahan Tumbuhan kepada Ibu PKK di Desa Sambirejo Timur Deli Serdang. Proseding Seminar Nasional, 258261.

2. Asrina, R. (2019). Formula Stabil Pasta Gigi dari Ekstraks Etanol Daun Gamal (Gliricida sepium) Sebagai Pencegah Karies Gigi. Jurnal Farmasi Sandi Karsa, V(2), 99-104.

3. Astika, Y., Saputro, A., \& Harismah, K. (2020). Formulasi Pasta Gigi Ekstrak Daun Jambu Biji dan Stevia Sebagai Antibakteri Alami . Toothpaste Formulation of Guava Leaf Extract and Stevia as Natural Antibacterial. Prosiding Seminar Nasional Biologi FMIPA UNM, 26-34.

4. Jannah, M., Dzakiah, A. A., \& Jumrawati. (2018). Inovasi Pasta Gigi Antiplak dan Antiseptik dari Daun Kemangi dan Daun Binahong. Journal Of Chemical Process Engineering, 03(01), $55-58$.

5. Nurdianti1, L., Annissya, W. ., Pamela, Y. ., Novianti, E., Audina, M., \& Kurniasari, E. (2016). Formula Sediaan Pasta Gigi Herbal Kombinasi Ekstrak Daun Sirih ( Piper betle ) dan Kulit Buah Jeruk Lemon ( Citrus limon) sebagai Pemutih dan Antiseptik pada Gigi. Jurnal Kesehatan Bakti Tunas Husad, 16.

6. Utari, P. W. (2018). Pembuatan Pasta Gigi Herbal Berbahan Dasar Kalsium Karbonat (CaCO3) dari Cangkang Kerang Mutiara ( Pinctada maksima ). Skripsi.

7. Ahmad M, Supriadi, Siti Nuryanti (2016) Pemanfaatan Biji Kelor (Moringa oleifera L.) Sebagai Pasta Gigi Jurnal Akademika Kimia, 5, (2), 61-66 